\title{
NDM-1- or OXA-48-producing Enterobacteriaceae colonising Polish tourists following a terrorist attack in Tunis, March 2015
}

R Izdebski ${ }^{1}$, K Bojarska ${ }^{1}$, A Baraniak ${ }^{1}$, E Literacka ${ }^{1}$, M Herda $^{1}$, D Żabicka ${ }^{1}$, A Guzek ${ }^{2}$, M Półgrabia ${ }^{2}$, W Hryniewicz ${ }^{1}$, M Gniadkowski (gniadkow@cls.edu.pl) ${ }^{1}$

1. National Reference Centre for Susceptibility Testing \& Department of Molecular Microbiology, National Medicines Institute, Warsaw, Poland

2. Military Institute of Medicine, Warsaw, Poland

Citation style for this article:

Izdebski R, Bojarska K, Baraniak A, Literacka E, Herda M, Żabicka D, Guzek A, Półgrabia M, Hryniewicz W, Gniadkowski M. NDM-1- or OXA-48-producing

Enterobacteriaceae colonising Polish tourists following a terrorist attack in Tunis, March 2015. Euro Surveill. 2015;20(23):pii=21150. Available online: http://www.

eurosurveillance.org/ViewArticle.aspx?Articleld=21150

We describe the introduction of NDM-1-producing Klebsiella pneumoniae ST147 and Escherichia coli ST410, and OXA-48-producing $K$. pneumoniae ST101 strains to Poland by two patients transported to the country after hospitalisation in Tunisia. The patients had gunshot wounds following the terrorist attack in the Bardo National Museum in Tunis in March 2015. Our report reinforces the need for microbiological screening of patients returning from travel on admission to healthcare institutions, especially following hospitalisation in countries where carbapenemaseproducing Enterobacteriaceae are endemic.

We describe two patients colonised by carbapenemase-producing Enterobacteriaceae (CPE), which were identified on and following admission of the patients to a hospital in Warsaw, Poland, in March 2015. The patients had gunshot wounds as a result of a terrorist attack in Tunis, Tunisia, and were transferred to Warsaw directly from a hospital in Tunis.

\section{following the terrorist attack}

On 18 March 2015, visitors at the Bardo National Museum in Tunis were attacked by a group of armed terrorists. A total of 24 people from different countries were killed and around 50 were injured by gunshot. According to the Poland's Ministry of Foreign Affairs, three Polish citizens died and 10 others were wounded, who were treated in several clinical centres in Tunis [1]. On 20 March, eight of the 10 less seriously injured Polish patients were transferred to a hospital in Warsaw (Hospital A), where they stayed in a surgical and then orthopaedic wards; the clinical records of these patients are not available.

The other two seriously injured Polish patients were operated on in the same surgical unit of a hospital in Tunis and stayed in there until 28 March (10 days), at which point they were transported by air to a surgical ward in Hospital B in Warsaw. The patients were microbiologically screened on admission and later monitored at least once a week during their hospitalisation. The specimens and body sites examined included blood, wounds and rectum, to test for the presence of CPE.

\section{Case description}

Patient $A$, in their late 50s, was shot in the sacrum during the attack. A rectal swab taken on admission yielded a Klebsiella pneumoniae isolate, identified by VITEK 2 (bioMérieux, Marcy l'Etoile, France) as carbapenem resistant. The isolate was subsequently tested for metallo-beta-lactamase (MBL)-, carbapenem-hydrolysing oxacillinase OXA-48- and $K$. pneumoniae carbapenemase (KPC)-like carbapenemases using CARBA NP and phenotypic tests [2-5]. The isolate was positive in Carba NP and the MBL EDTA double-disk test, and was resistant to temocillin, suggestive of OXA-48 [5]. Polymerase chain reaction (PCR) analysis for several carbapenemase genes [6] showed that the isolate was positive for bla ${ }_{\mathrm{NDM}}$ only and sequencing identified bla $a_{\mathrm{NDM}-1}$. The gene resided in a remnant of the Tn125 transposon, shown by PCR mapping to include the 3' part of the upstream ISAba125 element, the bla ${ }_{\mathrm{NDM}}$ ${ }_{-}-b_{\text {bBL }}$ operon, genes iso, tat, dct, groES and groEL, and to be truncated downstream of groEL $[7,8]$. By multilocus sequence typing (MLST) [9], the isolate was classified as sequence type (ST) 147. No CPE isolates were recovered from other sites of the patient either on admission or during hospitalisation.

Patient B, in their early 20s, had severe damage of subcutaneous tissue near the trochanter of the femur as a result of being shot. A rectal swab on admission yielded a carbapenem-resistant $K$. pneumoniae isolate that was Carba NP-positive, negative in MBL and KPC tests, but resistant to temocillin. PCR and sequencing 
showed $b l a_{\mathrm{OXA}-48}$ to be the only carbapenemase gene found. PCR mapping revealed that the gene was located in the Tn1999.2 transposon, with the upstream IS1999 element disrupted by IS1R [10]. The isolate was found to be ST101.

Ten days after admission, MBL-positive $K$. pneumoniae and Escherichia coli isolates were cultured from wound and rectal swabs. Isolates from the wound were analysed by molecular methods: both the K. pneumoniae and E. coli isolates were identified as New Delhi metallo-beta-lactamase-1 (NDM-1) producers; no other carbapenemases were found. The Tn125-like elements with their bla $a_{\mathrm{NDM}-1}$ genes produced the same PCR mapping pattern as that of the $K$. pneumoniae isolate from Patient $A$. The $K$. pneumoniae isolate belonged to ST147, whereas E. coli was classified by MLST [11] as ST410.

\section{Antimicrobial susceptibility testing}

Antimicrobial susceptibility of the CPE isolates from both patients was tested by MIC Test Strips (Liofilchem, Roseto degli Abruzzi, Italy) and interpreted according to the European Committee on Antimicrobial Susceptibility Testing (EUCAST) [12]. The isolates showed extensive resistance patterns, all being susceptible only to colistin, and all K. pneumoniae isolates to chloramphenicol (Table). Amikacin minimum inhibitory concentrations (MICs) of the four isolates indicated either susceptibility or intermediate resistance (EUCAST breakpoints: $\mathrm{S}$ $\leq 8 \mu \mathrm{g} / \mathrm{mL}, \mathrm{R}>16 \mu \mathrm{g} / \mathrm{mL}$ ).

\section{Discussion}

The global spread of CPE is a public health problem of great concern. MBLs of the NDM type and OXA-48-like oxacillinases are among the most frequently reported carbapenemases in CPE, mainly $K$. pneumoniae and $E$. coli. Their multiple emergence in many European countries has been often attributed to imported cases from the Indian subcontinent $[13,14]$ or the eastern and southern parts of the Mediterranean basin. These parts of the Mediterranean basin have been mostly associated with transmission of OXA-48-positive CPE. The second CPE transmitted from these areas was NDM-producing Acinetobacter species [13-15].

Partial molecular analysis revealed that the NDM-1producing isolates from both Polish patients probably had the same genetic context of the bla $a_{\mathrm{NDM}-1}$ gene, and both NDM-1-producing $K$. pneumoniae isolates were ST147. According to National Reference Centre for Susceptibility Testing records, the four isolates differed genetically from all NDM-1 or OXA-48 producers identified in Poland to date (data not shown). Therefore, the patients were most probably colonised in Tunisia, either during hospitalisation or, less likely, before the attack, outside the hospital setting.

It is unclear why NDM-1 producers from Patient B were recovered only 10 days after admission to a Warsaw hospital. Both patients had shared common care 
exposure in the Tunis hospital and it is possible that the fact that the cultures were NDM negative on admission to the hospital in Warsaw was due to limited sensitivity of the screening.

In the Warsaw hospital, a set of enhanced infection control measures were used, including separate rooms with dedicated sanitary facilities, strict contact isolation and dedicated equipment. Nevertheless, transmission from Patient $A$ to Patient $B$ in Warsaw cannot be entirely excluded, especially as both patients were treated by the same personnel. To date, no secondary transmission of the CPE to other patients in the hospital has been observed. To date, Patient $A$ is still hospitalised whereas Patient B was discharged on 22 April 2015. Control measures are in place: all patients admitted to high-risk wards, such as intensive-care units, surgery, haematology and oncology, are screened on admission.

Although a number of reports have indicated North Africa as a reservoir of OXA-48- and NDM-producing organisms, lack of local surveillance data impedes full assessment of the situation there. Some reviews articles have shown these organisms as being of 'sporadic occurrence' in that region [13-17], especially NDMpositive Enterobacteriaceae, which have been reported in North African countries only a few times [15], including one NDM-1- and OXA-48-producing $K$. pneumoniae ST11 isolate recovered in Tunisia from a Libyan patient in 2012 [18].

ST101 and ST147 are emerging clones of $K$. pneumoniae, found worldwide with various beta-lactamases, including carbapenemases [19]. K. pneumoniae ST101 with OXA-48 encoded by Tn1999.2 was described in Tunisia and other North African countries $[16,20,21]$. K. pneumoniae ST147 with NDM-1, as well as NDM-1-producing pandemic E. coli ST410, have been reported in many regions, but to the best of our knowledge not in North Africa [22-26]. Our report once again reinforces the need for microbiological screening of patients returning from travel, especially following hospitalisation in countries where CPE are endemic, as specified, for example, in Polish infection control guidelines [27].

\section{Acknowledgments}

This work was supported by the grant UMO-2012/07/B/ NZ6/03528 from the Polish National Science Centre.

\section{Conflict of interest}

None declared.

\section{Authors' contributions}

$\mathrm{RI}$ performed the molecular analysis, collected the data and drafted the manuscript; KB performed the microbiological analysis; $A B$ performed the molecular analysis and collected the data; EL performed the microbiological analysis; $\mathrm{MH}$ performed the microbiological analysis; DŻ coordinated the microbiological analysis; AG performed the hospital laboratory analysis and collected the isolates with clinical data; MP coordinated the hospital infection control measures and collected the clinical data; WH consulted the cases and edited the manuscript; MG supervised the research and analysis, coordinated and edited the manuscript.

\section{References}

1. Polish Ministry of Foreign Affairs. Aktualny bilans ofiar zamachu terrorystycznego w Tunezji - trzecia polska ofiara śmiertelna. [Updated information on victims of the terrorist attack in Tunisia - the third killed person from Poland]. Warsaw: Polish Ministry of Foreign Affairs; 20 March 2015. Polish. Available from http://www.msz.gov.pl/pl/ aktualnosci/wiadomosci/aktualny_bilans_ofiar_zamachu_ terrorystycznego_w_tunezji_-_trzecia_polska_ofiar_ smiertelna

2. Nordmann P, Poirel L, Dortet L. Rapid detection of carbapenemase-producing Enterobacteriaceae. Emerg Infect Dis. 2012;18(9):1503-7. http://dx.doi.org/10.3201/ eid1809.120355 PMID:22932472

3. Lee K, Lim YS, Yong D, Yum JH, Chong Y. Evaluation of the Hodge test and the imipenem-EDTA double-disk synergy test for differentiating metallo- $\beta$-lactamase-producing isolates of Pseudomonas spp. and Acinetobacter spp. J Clin Microbiol. 2003;41(10):4623-9. http://dx.doi.org/10.1128/JCM.41.10.46234629.2003 PMID:14532193

4. Doi Y, Potoski BA, Adams-Haduch JM, Sidjabat HE, Pasculle AW, Paterson DL. Simple disk-based method for detection of Klebsiella pneumoniae carbapenemase-type $\beta$-lactamase by use of a boronic acid compound. J Clin Microbiol. 2008;46(12):4083-6. http://dx.doi.org/10.1128/JCM.01408-08 PMID:18923005

5. Glupczynski Y, Huang TD, Bouchahrouf W, Rezende de Castro $R$, Bauraing C, Gérard M, et al. Rapid emergence and spread of OXA-48-producing carbapenem-resistant Enterobacteriaceae isolates in Belgian hospitals. Int J Antimicrob Agents. 2012;39(2):168-72. http://dx.doi.org/10.1016/j. ijantimicag.2011.10.005 PMID:22115539

6. Papagiannitsis CC, Izdebski R, Baraniak A, Fiett J, Herda M, Hrabák J, et al.; MOSAR WP $2, W_{3}$ and WP 5 study groups; MOSAR WP 2 WP 3 and WP 5 study groups. Survey of metallo- $\beta$ lactamase-producing Enterobacteriaceae colonizing patients in European ICUs and rehabilitation units, 2008-11. J Antimicrob Chemother. 2015. PMID:25759034

7. Toleman MA, Spencer J, Jones L, Walsh TR. blaNDM-1 is a chimera likely constructed in Acinetobacter baumannii. Antimicrob Agents Chemother. 2012;56(5):2773-6. http:// dx.doi.org/10.1128/AAC.06297-11 PMID:22314529

8. Poirel L, Bonnin RA, Boulanger A, Schrenzel J, Kaase M, Nordmann P. Tn125-related acquisition of blaNDM-like genes in Acinetobacter baumannii. Antimicrob Agents Chemother. 2012;56(2):1087-9. http://dx.doi.org/10.1128/AAC.05620-11 PMID:22143526

9. Diancourt L, Passet V, Verhoef J, Grimont PA, Brisse S. Multilocus sequence typing of Klebsiella pneumoniae nosocomial isolates. J Clin Microbiol. 2005;43(8):417882. http://dx.doi.org/10.1128/JCM.43.8.4178-4182.2005 PMID:16081970

10. Carrër A, Poirel L, Yilmaz M, Akan OA, Feriha C, Cuzon G, et al. Spread of OXA-48-encoding plasmid in Turkey and beyond. Antimicrob Agents Chemother. 2010;54(3):1369-73. http:// dx.doi.org/10.1128/AAC.01312-09 PMID:20086157

11. Wirth T, Falush D, Lan R, Colles F, Mensa P, Wieler LH, et al. Sex and virulence in Escherichia coli: an evolutionary perspective. Mol Microbiol. 2006;60(5):1136-51. http://dx.doi.org/10.1111/ j.1365-2958.2006.05172.x PMID:16689791

12. European Committee on Antimicrobial Susceptibility Testing (EUCAST). Clinical breakpoints. Breakpoint table for bacteria. Version 5.0, 2015. [Accessed 20 May 2015]. Available from http://www.eucast.org/fileadmin/src/media/PDFs/EUCAST_ files/Breakpoint_tables/v_5.0_Breakpoint_Table_01.pdf

13. Dortet L, Poirel L, Nordmann P. Worldwide dissemination of the NDM-type carbapenemases in Gram-negative bacteria. Biomed Res Int. 2014;2014:249856. doi: 10.1155/2014/249856 PMID: 24790993

14. Poirel L, Potron A, Nordmann P. OXA-48-like carbapenemases: the phantom menace. I Antimicrob Chemother. 2012;67(7):1597606. http://dx.doi.org/10.1093/jac/dks121 PMID:22499996

15. Djahmi N, Dunyach-Remy C, Pantel A, Dekhil M, Sotto A, Lavigne JP. Epidemiology of carbapenemase-producing Enterobacteriaceae and Acinetobacter baumannii in 
Mediterranean countries. Biomed Res Int. 2014;2014:305784. doi: 10.1155/2014/305784 PMID: 24955354

16. Potron A, Poirel L, Rondinaud E, Nordmann P. Intercontinental spread of OXA-48 $\beta$-lactamase-producing Enterobacteriaceae over a 11-year period, 2001 to 2011. Euro Surveill. 2013;18(31):20549. http://dx.doi.org/10.2807/1560-7917. ES2013.18.31.20549 PMID:23929228

17. Nordmann P, Poirel L. The difficult-to-control spread of carbapenemase producers among Enterobacteriaceae worldwide. Clin Microbiol Infect. 2014;20(9):821-30. http:// dx.doi.org/10.1111/1469-0691.12719 PMID:24930781

18. Ben Nasr A, Decré D, Compain F, Genel N, Barguellil F, Arlet G. Emergence of NDM-1 in association with OXA-48 in Klebsiella pneumoniae from Tunisia. Antimicrob Agents Chemother. 2013;57(8):4089-90. http://dx.doi.org/10.1128/AAC.00536-13 PMID:23752514

19. Woodford N, Turton JF, Livermore DM. Multiresistant Gram-negative bacteria: the role of high-risk clones in the dissemination of antibiotic resistance. FEMS Microbiol Rev. 2011;35(5):736-55. http://dx.doi.org/10.1111/j.15746976.2011.00268.x PMID:21303394

20. Lafeuille E, Decré D, Mahjoub-Messai F, Bidet P, Arlet G, Bingen E. OXA-48 carbapenemase-producing Klebsiella pneumoniae isolated from Libyan patients. Microb Drug Resist. 2013;19(6):491-7. http://dx.doi.org/10.1089/mdr.2012.0219 PMID:23808959

21. Pitart C, Solé M, Roca I, Fàbrega A, Vila J, Marco F. First outbreak of a plasmid-mediated carbapenem-hydrolyzing OXA$48 \beta$-lactamase in Klebsiella pneumoniae in Spain. Antimicrob Agents Chemother. 2011;55(9):4398-401. http://dx.doi. org/10.1128/AAC.00329-11 PMID:21746954

22. Fiett J, Baraniak A, Izdebski R, Sitkiewicz I, Żabicka D, Meler $A$, et al. The first NDM metallo- $\beta$-lactamase-producing Enterobacteriaceae isolate in Poland: evolution of IncFll-type plasmids carrying the bla(NDM-1) gene. Antimicrob Agents Chemother. 2014;58(2):1203-7. http://dx.doi.org/10.1128/ AAC.01197-13 PMID:24247128

23. Poirel L, Dortet L, Bernabeu S, Nordmann P. Genetic features of blaNDM-1-positive Enterobacteriaceae. Antimicrob Agents Chemother. 2011;55(11):5403-7. http://dx.doi.org/10.1128/ AAC.00585-11 PMID:21859933

24. Samuelsen $\emptyset$, Thilesen CM, Heggelund L, Vada AN, Kümmel A, Sundsfjord A. Identification of NDM-1-producing Enterobacteriaceae in Norway. I Antimicrob Chemother. 2011;66(3):670-2. http://dx.doi.org/10.1093/jac/dkq483 PMID:21172785

25. Peirano G, Ahmed-Bentley J, Fuller J, Rubin JE, Pitout JD. Travel-related carbapenemase-producing Gram-negative bacteria in Alberta, Canada: the first 3 years. J Clin Microbiol. 2014;52(5):1575-81. http://dx.doi.org/10.1128/JCM.00162-14 PMID:24599977

26. Giske CG, Fröding I, Hasan CM, Turlej-Rogacka A, Toleman $M$, Livermore $D$, et al. Diverse sequence types of Klebsiella pneumoniae contribute to the dissemination of blaNDM-1 in India, Sweden, and the United Kingdom. Antimicrob Agents Chemother. 2012;56(5):2735-8. http://dx.doi.org/10.1128/ AAC.06142-11 PMID:22354295

27. Hryniewicz W. Zalecenia dotyczące postępowania w przypadku zachorowań sporadycznych I ognisk epidemicznych wywołanych przez Gram-ujemne pałeczki z rodziny Enterobacteriaceae. Zalecenia dotyczące postępowania w przypadku identyfikacji w podmiotach wykonujących dziatalność leczniczą szczepów bakteryjnych Enterobacteriaceae wytwarzających karbapenemazy typu KPC, MBL lub OXA-48. [Guidelines for infection control measures in case of sporadic and epidemic infection caused by Enterobacteriaceae. Recommendations for infection control measures in case of identification of carbapenemaseproducing Enterobacteriaceae (KPC, MBL and OXA-48 types)]. Warsaw: Polish Ministry of Health; 2012. Polish. Available from http://www.antybiotyki.edu.pl/pdf/kpc-20120713.pdf 